\title{
IS DELAY SELLING SYSTEM GOOD FOR INDONESIA'S AGRIBUSINESS MANAGEMENT?
}

\author{
Pariasa Imaniar IImi ${ }^{\star}$, Hardana Andrean Eka, Koestiono Djoko \\ Faculty of Agriculture, University of Brawijaya, Malang, Indonesia \\ *E-mail: pariasa 17@yahoo.com
}

\begin{abstract}
Delay selling practice is the one of strategys to solve price fluctuation for agricultural commodity in harvest time. It's still become a problem for farmers even the goverment already have many program to solved that isued.One of the efforts to reduce price fluctuation and oversupply of agricultural yields in harvest time is by developing delay selling system model referring to specific local condition. This Study were to describe the implementation of delay selling activity conducted by farmers, and analyze the impact of delay selling implementation on agribusiness development with descriptive and quantitative method. The result shows that delay selling activityin rice farming business gives more revenue compared to non-delay selling activity. Although the cost of delay selling is higher than those who do not implement delay selling activity, the implementation of delay selling activity gives more benefits by comparing the difference of selling price of rice in each kilogram.
\end{abstract}

\section{KEY WORDS}

Delay selling activity, Agribusiness, development, farmers.

According to Ashari (2010), the phenomenon of falling prices for agricultural commodity in harvest time has already become a serious problem for farmers and still cannot be solved. It clearly illustrates that farmers do not have power in facing price fluctuation either on food commodity, horticulture, or plantations. Price fluctuation can be engendered by ample supply and demand. When supply is getting abundant, the price is getting lower and vice versa (ceteris paribus). Abundant and inadequate supplies are engendered by harvest time, and high crop failures because of pest attacks and climate factors (Muharlis, 2007). Based on Food Security Service (2014), one of the efforts to reduce price fluctuation and oversupply of agricultural yields in harvest time is by developing delay selling system model referring to specific local condition.

According to Ashari (2010), the phenomenon of falling prices for agricultural commodity in harvest time has already become a serious problem for farmers and still cannot be solved. It clearly illustrates that farmers do not have power in facing price fluctuation either on food commodity, horticulture, or plantations. Price fluctuation can be engendered by ample supply and demand. When supply is getting abundant, the price is getting lower and vice versa (ceteris paribus). Abundant and inadequate supplies are engendered by harvest time, and high crop failures because of pest attacks and climate factors (Muharlis, 2007). Based on Food Security Service (2014), one of the efforts to reduce price fluctuation and oversupply of agricultural yields in harvest time is by developing delay selling system model referring to specific local condition.

The development of delay selling system model in the central food production is intended to strengthen the capitalization of farmers group which still becomes a big problem in food commodity marketing. By implementing this activity, the bargaining position and selling price of farmers' products will hopefully increase. Thus, the target to improve farmers' income and regional food security can be realized.This implementation of delay selling system will prioritize farmers through several approaches on farmers groups, e.g. human resources empowerment, and management and capitalization competencies. 


\section{METHODS OF RESEARCH}

The research site was in Tanggul subdistrict, Jember regency of East Java. The research site was chosen based on the data of paddy production centre in Indonesia in which East Java is one of the greatest paddy production centres in Indonesia. According to BPS (2011), East Java is the second place of paddy production after West Java. East Java is one of national rice needs supports. The research was started from April to November 2017.

\section{RESULTS AND DISCUSSION}

Delay selling activity in Selodakon village was implemented by Gapoktan Mutiara Tani. This kind of activity was supported by grant program from East Java Province. The grant program which was given to Gapoktan Mutiara Tani was Lembaga Distribusi Pangan Masyarakat (LDPM) program. Gapoktan had two divisions at the beginning of its formation; they were breeding and post-harvest business division including grain forwarding up to marketing distribution. Gapoktan Mutiara Tani obtained LDPM's grant by competing with other gapoktan surrounding Jember Regency in Food Security Service of Jember Regency.

LDPM program has become one of government policy program in achieving food security. This program is held in farmer level which obligates Gapoktan to conduct two activities as community food reserve and as distributor or marketing division, especially in rice commodity. The implementation of this program was merged in which, at the beginning, marketing activity became part of post-harvest business division, then, it becomes an independent marketing business unit. Yet, the activity of community food reserve is still operating in accordance with the term and conditions of the program.LDPM program is intended to empower Gapoktan institution in order to be able to perform food distribution activity and food reserve provision, as well as to improve Gapoktan's ability and its managed business units in fostering food reserve and existing capital.

In 2016, there were 5 (five) divisions or business units, such as Rice Milling Unit (RMU), Distribution (Agricultural Product Marketing), Food Reserve, Agricultural Breeding, and Agribusiness Micro Finance Institution. One of business units performed based on delay selling implementation is Rice Milling Unit (RMU).

Rice Milling Unit (RMU) has a role in post-harvest activity of rice commodity. The activities in RMU or agricultural yield processes are processing from grain until packaging. In addition, this unit also provides grain storage or grain delay selling. The required grain is dried and ground grain. Dried grain has maximum moisture content $14 \%$, maximum dirt / vacuum content $3 \%$, green grain / maximum calcify $5 \%$, maximum yellow / damaged grains $3 \%$, and maximum red grains $3 \%$.

In operating grain forwarding, farmers technically bring the dried and ground grains to be forwarded to RMU based on farmers' needs. This unit also provides the facility of rice drying. The capacity of rice grinding is 1 ton per hour. In addition, Rice Milling Unit also do packaging in 25 kilograms weight. Rice Milling Unit or RMU do both grinding and storing for farmers who implement delay selling. Partial storage was applied in order farmers feel more safe and flexible as they want to sell or take their grain. Storage or delay selling rice was done in this unit. The storage was done if farmers store their grain with the predetermined quantity. The storage was applied to delay the selling because of low selling price. Farmers implement delay selling until the selling price is getting higher. Farmers store their grain in primary warehouse located at southern village hall. Its capacity reaches 10 tons.

Revenue earned from farming business affects high or low farmers' income from conducting rice farming business. Income earned by farmers is calculated from the difference between total revenue and total cost production. Thus, the income earned by respondents can be known from revenue and total cost. The average revenue earned by farmer in one planting period is shown in table 1.

The result of income analysis showed that farmers who implement delay selling have higher income or profit than those who do not implement delay selling. Delay selling actors earned an income Rp. 14.378.020 in average, while non-delay selling actors earned an 
income Rp. 9.979.000. The difference income was caused by a difference total revenue earned between delay selling and non-delay selling actors.

Table 1 - Revenue of Rice Farming

\begin{tabular}{llll}
\hline \multirow{2}{*}{ No } & \multirow{2}{*}{ Component } & \multicolumn{2}{l}{ Average of Rice Farming Revenue } \\
\cline { 3 - 4 } & & Delay Selling (Rp) & Non Delay Selling (Rp) \\
\hline 1 & Average of Revenue & 23.142 .474 & 17.196 .309 \\
2 & Average of Total Cost & 8.764 .454 & 7.217 .309 \\
\hline Average of Income & 14.378 .020 & 9.979 .000 \\
\hline
\end{tabular}

Source: Primary data, 2017.

Total revenue earned by delay selling actors reached $\mathrm{Rp}$. 23.142.474 with selling price Rp. 5.520 per kilogram. While, non-delay selling actors earned Rp. 17.196 .309 with selling price Rp. 3.500 per kilogram.Although the cost of delay selling actors is higher than those who do not implement delay selling activity, the implementation of delay selling activity gives more benefits than non-delay selling by comparing the difference of selling price of rice per kilogram.

\section{CONCLUSION AND SUGGESTIONS}

The implementation of delay selling activity in rice farming business was conducted by Rice Milling Unit (RMU) managed by GapoktanMutiaraTani. This unit provides mill and storage for farmers who want to delay their selling. Rice storage can be done partially so that farmers feel safe and flexible when they want to sell or take their grains. Furthermore, it is supported by warehouse facility with the capacity reaching 10 tons.

Agribusiness development in rice farming business with delay selling activity gives more benefits compared to non-delay selling activity. Regarding total cost, delay selling actors have higher cost than those non-delays selling but the difference of rice selling price per kilogram makes delay selling actors obtain more profit than those non-delays selling. Agribusiness development was also conducted by farming Business Corporation in which the farmers (i.e. farmers group MutiaraTani) in Selodakon Village runs it. As a start, pilot project with 10 hectare rice field was applied with irrigation technique starting from breeding to postharvest.

As supporting facility, the capacity of grain storage in Gapoktan warehouse can be enlarged by expanding storage place and area of grain drying to accommodate the needs of seven farmer groups in order to participate in delay selling activity.

The government can support the sustainable of this program especially for marketing aspect by cooperating GapoktanMutiaraTani with Bulog institution in Jember district.

\section{REFERENCES}

1. Agriculture Research and Development Berau. (2005). Sugar Cane in Indonesia. Agriculture Berau. Jakarta.

2. Ashari. 2010. Prospect of Warehouse Receipt System As an Alternative to Agricultural Sector Financing. Bogor: Center for Socio-Economic and Agricultural Policy, Ministry of Agriculture.

3. Ashari. 2012. Potential and Constraints of Warehouse Receipt Systems to Support Agricultural Business Financing in Indonesia. Bogor: Center for Socio-Economic and Agricultural Policy, Ministry of Agriculture.

4. Bernatonyte, D. Burksaitiene, D. \& Rimiene, K. (2013). Trade Specialization Pattern of Lithuania. Economics and Management: 2013. 18 (4).

5. Bernatonyte, D. \& Normantiene, A. (2009). Estimation of Trade Specialization: the Case of the Baltic States. Ekonomika-Engineering Economics (2).

6. Burger, K. Kameo, D. \& Sandee, H. (2001). Clustering of Small Agro-Processing Firms in Indonesia. International Food and Agribusiness Management Review, 2 (3/4): 289-299. 
7. Caporale, G. M. \& Sova, R. (2015). Trade Flows And Trade Specialisation: The Case Of China. Working Paper No. 15-07.

8. Center for Domestic Trade Policy Agency for the Assessment and Development of Trade Policy of the Ministry of Trade. (2015). Analysis of the Effectiveness of Warehouse Receipt Systems through the Integration of the Commodity Forward Auction Market. Jakarta: Puska Dagri, BP2KP, Ministry of Trade.

9. Churmen, Imam (2001). Save sugar industry in Indonesia. Millenium Publisher. Jakarta.

10. Dachliani, D. (2006). Demand of sugar import on 1980-2003 in Indonesia. (Thesis). Faculty of Economic. Diponegoro University. Semarang.

11. Delroy Anthony Armstrong (2004). The Potential Impact of Trade Policychanges on Caribbean Sugar. B.S., Louisiana State University.

12. Dipl.-Ing. Dieter Bahndorf, Udo Kienle. (2004). World Market of Sugar and Sweeteners. OECD-FAO Agricultural Outlook 2016-2025, OECD Publishing, Paris.

13. Firmansyah, (2008). The Position of Competitiveness and Specialization Trading of Tealndonesia in Facing Globalization.Brawijaya. University. Malang.

14. Food Security Agency and Implementing Agency. 2014. Sistem Resi Gudang. Diakses pada http://bkppp.bantulkab.go.id/data/hal/5/9/27/94-tentang-sistem-resi-gudang-srg.

15. Gaynor, P.E., and R.C. Kirk Patrick. (1994). Tome Series Modeling and Forecasting in Business and Economics. New York, Mc Graw hill.

16. Haley, Stephen.2013. World Raw Sugar Prices The Influence of Brazilian Costs of Production and World Surplus/ Deficit Measures. United States Department of Agriculture.

17. Laws of the republic Indonesia. 2005. Undang-undang Republik Indonesia Nomor 9 Tahun 2006 tentang Sistem Resi Gudang. Jakarta.

18. Matsumura, Kanichiro. (2010). Demand and Supply Structure for Food in Asia. Sustainability 2011, 3, 363-395; doi:10.3390/su3020363.

19. Maulidah, Silvana. 2012. Agribusiness System. Faculty of Agriculture. Malang: Brawijaya University.

20. McConnell, Michael; Erik Dohlman; Stephen Haley. (2010). World Sugar Price Volatility Intensified by Market and Policy Factors.

21. McCormick, A. J. Watt, D. A. and Cramer, M. D. (2009). Supply and demand: sink regulation of sugar accumulation in sugarcane. Journal of Experimental Botany, Vol. 60, No. 2, pp. 357-364.

22. Pertani. 2012. Background of Warehouse Receipt System. Diakses pada https://pertaniupgjatim.wordpress.com/2012/07/12/latar-belakang-sistem-resi-gudang/

23. Riana, Dina. 2010. Use of Warehouse Receipt System. Faculty of Law. Jakarta: University of Indonesia.

24. Rumánková, Lenka and Smutka, Luboš. (2013). Global Sugar Market - The Analysis of Factors Influencing Supply and Demand. Volume LXI. No. 2, pp. 463-471.

25. Sa'diyah, C. (2014). Factors that influence of economic performance for crystal sugar in Indonesia. (Thesis). Faculty of Agriculture. University of Brawijaya. Malang.

26. Sinaga, N. (2006). Model Econometric Aplication. IPB Post Graduate. Bogor.

27. Susila, Wayan.R and Bonar M. Sinaga. (2005). Analysis of Sugar Industry Policy in Indonesia. Jurnal Agro - Ekonomi Volume 23 No. 1, page 30-53.

28. Xue Xu and Hailong Xia. (2014). Analysis and Outlook of China's Sugar Industry Development. Proceedings of Selected Articles of 2013 World Agricultural Outlook. 